\title{
Grey water biodegradability
}

\author{
Lina Abu Ghunmi - Grietje Zeeman • \\ Manar Fayyad · Jules B. van Lier
}

Received: 13 September 2009/ Accepted: 27 June 2010/Published online: 25 July 2010

(C) Springer Science+Business Media B.V. 2010

\begin{abstract}
Knowing the biodegradability characteristics of grey water constituents is imperative for a proper design and operation of a biological treatment system of grey water. This study characterizes the different COD fractions of dormitory grey water and investigates the effect of applying different conditions in the biodegradation test. The maximum aerobic and anaerobic biodegradability and conversion rate for the different COD fractions is determined. The results show that, on average, dormitory grey water COD fractions are $28 \%$ suspended, $32 \%$ colloidal and $40 \%$ dissolved. The studied factors incubation time, inoculum addition and temperature are influencing the determined biodegradability. The maximum biodegradability and biodegradation rate differ between different COD fractions, viz. $\mathrm{COD}_{\mathrm{ss}}$,
\end{abstract}

L. Abu Ghunmi $(\bowtie) \cdot$ M. Fayyad

Water and Environment Research Study Center,

The University of Jordan, P.O. Box 1300,

Amman 11942, Jordan

e-mail: Lina.abughunmi@ju.edu.jo;

Linagh22@yahoo.co.uk

L. Abu Ghunmi · G. Zeeman

Department of Agrotechnology and Food Sciences,

Sub-Department of Environmental Technology,

Wageningen University, P.O. Box 8129, 6700 EV

Wageningen, The Netherlands

\section{J. B. van Lier}

Section Sanitary Engineering, Department of Water

Management, Delft University of Technology,

P.O. Box 5048, 2600 GA Delft, The Netherlands
$\mathrm{COD}_{\text {col }}$ and $\mathrm{COD}_{\text {diss }}$. The dissolved COD fraction is characterised by the lowest degradation rate, both for anaerobic and aerobic conditions. The maximum biodegradability for aerobic and anaerobic conditions is 86 and $70 \%$ respectively, whereas the first order conversion rate constant, $k_{20}$, is 0.119 and 0.005 day $^{-1}$, respectively. The anaerobic and aerobic conversion rates in relation to temperature can be described by the Arrhenius relation, with temperature coefficients of 1.069 and 1.099, respectively.

Keywords Anaerobic A Aerobic .

Biodegradability $\cdot$ Rate $\cdot$ Grey water .

Temperature

\section{Nomenclatures}

$\begin{array}{ll}\text { APE } & \text { Alkyl-phenol ethoxylate } \\ \text { BMP } & \text { Biological methane potential } \\ \text { BOD } & \text { Biochemical oxygen demand } \\ C & \text { Substrate concentration } \\ C_{0} & \text { Initial substrate concentration } \\ { }^{\circ} \mathrm{C} & \text { Celsius } \\ \mathrm{CH}_{4} & \text { Methane } \\ \mathrm{COD} & \text { Chemical oxygen demand } \\ \mathrm{Col} & \text { Colloidal } \\ \mathrm{CSTR} & \text { Continuous stirred tank reactor } \\ \text { DEEDMAC } & \begin{array}{l}\text { Diethyl ester dimethyl ammonium } \\ \text { chloride }\end{array} \\ \text { dis } & \text { Dissolved } \\ \text { EXP } & \text { Exponential } \\ \text { fra } & \text { Fraction }\end{array}$




$\begin{array}{ll}\text { HRT } & \text { Hydraulic retention time } \\ k & \text { Kinetic rate constant } \\ \text { LAS } & \text { Liner alkyl benzene sulphonate } \\ \text { Ln } & \text { Natural logarithm } \\ \text { MBR } & \text { Membrane biological reactor } \\ \text { MCR } & \text { Membrane chemical reactor } \\ \text { mf } & \text { Membrane filtrate } \\ \text { MW } & \text { Molecular weight } \\ \text { MWCO } & \text { Molecular-weight cut-off } \\ \text { pf } & \text { Paper filtrate } \\ \text { SLS } & \text { Sodium laurel sulphate } \\ \text { SRT } & \text { Sludge retention time } \\ \text { ss } & \text { Suspended solids } \\ t & \text { Time } \\ T & \text { Temperature } \\ \text { tot } & \text { Total } \\ \text { TVS } & \text { Total volatile solids } \\ \text { UASB } & \text { Up-flow anaerobic sludge blanket } \\ \text { UBOD } & \text { Ultimate BOD } \\ \text { VSS } & \text { Volatiles suspended solids } \\ \theta & \text { Temperature coefficient }\end{array}$

\section{Introduction}

Grey water is domestic wastewater without the input from toilets (Jefferson et al. 2004; Eriksson et al. 2002; Christova-Boal et al. 1995), sometimes kitchen wastewater is excluded as well (Nolde et al. 1999). Grey water constituents form $38 \%$, and up to $71 \%$ of the COD of domestic wastewater when excluding and including kitchen wastewater respectively (Kujawa-Roeleveld and Zeeman 2006). Different biological treatment processes have been investigated to stabilise grey water (Nolde 1999; Jefferson et al. 1999, 2000, 2001; Li et al. 2003; Friedler et al. 2005, 2006; Elmitwalli and Otterpohl 2007; Shin et al. 1998; Hernandez et al. 2007, 2008). Evaluation of treatment performances, of which biological processes, reveal that grey water constituent are partly recalcitrant (Jefferson et al. 2001), slowly sometimes even non-biodegradable (Friedler et al. 2006). In addition grey water contains soluble organic matter with a low molecular weight; i.e. retained by a "MWCO 200 Dalton membrane" nano-filtration unit (Ramon et al. 2004). Thus many researches have been directed towards the use of Membrane Biological Reactor (MBR) (Jefferson et al. 2000, 2001; Friedler et al. 2006), and membrane chemical reactor (MCR) systems (Rivero et al. 2006; Winward et al. 2008). The basic requirements to design and operate the biological processes are the amount of biodegradable organic matter and the rate of biodegradation at different temperatures. However, so far, little has been done concerning the biodegradability of grey water constituents, e.g. by Elmitwalli and Otterpohl (2007) and Zeeman et al. (2008).

Grey water biodegradation starts under anaerobic conditions within 2 days of storage (Dixon et al. 1999). The biodegradable fraction of grey water constituents, measured as COD, is $74 \pm 4 \%$ (Elmitwalli and Otterpohl 2007) and $72 \pm 12 \%$ (Zeeman et al. 2008) under anaerobic conditions and is about $84 \pm 5 \%$ under aerobic conditions (Zeeman et al. 2008). Literature results show that the ratio of $\mathrm{BOD}_{5}$ to COD is low and varies from 0.25 to 0.64 (Jefferson et al. 1999; and compiled from Friedler et al. 2005, 2006; Winward et al. 2008). Surfactants such as LAS, Alcohol sulfates, SLS, APE and DEEDMAC are common grey water constituents and their biodegradability differ between aerobic and/or anaerobic conditions (Berna et al. 1999).

In general, biodegradability results are influenced by the test conditions such as the initial concentration, the incubation time, the used inoculum, and the temperature (Angelidaki and Sanders 2004; Metcalf and Eddy 2003). The effect of these test conditions on the biodegradation of grey water has not been investigated therefore the biodegradability results cannot be evaluated and generalized. Thus this paper characterizes combined grey water from shower, hand washbasins and laundry in terms of COD of the different particle size fractions and studies the aerobic and anaerobic biodegradability of the grey water. To do this, experiments and tests were done to investigate the factors influencing the biodegradability percentage and conversion rate of the grey water under anaerobic and aerobic conditions. Maximum biodegradability and biodegradation rates of various grey water fractions were determined and the effect of temperature on the biodegradation rates of grey water was established.

\section{Methodology}

Grey water source and sampling

The source of the grey water used for this study, as in Abu Ghunmi et al. (2008, 2010), was the waste streams 
of shower, laundry and washbasins discharged into a single outlet pipe of a 150-female dormitory at the Jordan university campus. As described in Abu Ghunmi et al. (2010) the outlet pipe was retrofitted so that it discharged the wastewater, $7 \mathrm{~m}^{3}$, directly into the pilot plant. An Auto-sampler collected daily composite samples from the inlet pipe of the pilot plant. The auto-sampler (ISCO, 6712), consisting of 24 1-1 bottles, was programmed to withdraw every $15 \mathrm{~min} 250 \mathrm{ml}$ of grey water; for maximum frequency and volume in collecting grey water. For analysis a daily composite sample was prepared on-site, by mixing the content of the 24 bottles in one container of which 31 was taken for analysis, performed on the same day. In this way 60 composite grey water samples were collected and analysed over a period of 2 years.

Preparation of grey water samples, inoculum, nutrient and buffer solutions for batch tests

Grey water sample preparation entailed 31 per day of fresh grey water composite samples of which 21 were filtered through Whatman No. 40 filter paper $(8 \mu \mathrm{m})$. One litre of the latter filtrate was filtered through Whatman No. 42 filter paper $(2.5 \mu \mathrm{m})$ and then through $0.45 \mu \mathrm{m}$ membrane filters. The aerobic inoculum consisted of the effluent of the activated sludge units of the Abu-Nussier domestic wastewater treatment plant. 11 fresh activated sludge effluent was collected and filtered through Whatman No. 40 filter paper and the filtered liquid was used as inoculum. Anaerobic inoculum was taken from a $1.4 \mathrm{~m}^{3}$ UASB-pilot plant at the Abu-Nussier domestic wastewater treatment plant. 11 anaerobic flocculent sludge was collected from the bottom, middle and upper taps; the sludge from the three taps were mixed together and then analyzed for VSS. The minimum COD to VSS, feed/sludge, ratio applied in the anaerobic biodegradability tests was 0.5 (Analysis manuals; Sub-Department of Environmental Technology, Wageningen University).

Different solutions were prepared and used within the research. A $300 \mathrm{mg} \mathrm{COD}^{-1}$ glucose solution was prepared with distilled water. A $10 \mathrm{mM}$ phosphate buffer solution was prepared. The supplied micronutrient solution (Alphenaar 1994) was composed of $2 \mathrm{~g} \mathrm{l}^{-1} \mathrm{FeCl}_{3} \cdot 4 \mathrm{H}_{2} \mathrm{O}, 2 \mathrm{~g} \mathrm{l}^{-1} \mathrm{CoCl}_{2} \cdot 6 \mathrm{H}_{2} \mathrm{O}$, $0.5 \mathrm{~g} \mathrm{l}^{-1} \quad \mathrm{MnCl}_{2} \cdot 4 \mathrm{H}_{2} \mathrm{O}, 30 \mathrm{mg} \mathrm{l}^{-1} \quad \mathrm{CuCl}_{2} \cdot 2 \mathrm{H}_{2} \mathrm{O}$,
$50 \mathrm{mg} \mathrm{l}^{-1} \mathrm{ZnCl}_{2}, \quad 50 \mathrm{mg} \mathrm{l}^{-1} \quad \mathrm{HBO}_{3}, \quad 90 \mathrm{mg} \mathrm{l}^{-1}$ $\left(\mathrm{NH}_{4}\right)_{6} \mathrm{Mo}_{7} \mathrm{O}_{24} \cdot 4 \mathrm{H}_{2} \mathrm{O} \mathrm{mg} \mathrm{l^{-1 }}, 100 \mathrm{mg} \mathrm{l}^{-1} \mathrm{Na}_{2} \mathrm{SeO}_{3}$. $5 \mathrm{H}_{2} \mathrm{O}, \quad 50 \mathrm{mg} \mathrm{l}^{-1} \quad \mathrm{NiCl}_{2} \cdot 6 \mathrm{H}_{2} \mathrm{O}, \quad 1 \mathrm{~g} \mathrm{l}^{-1}$ EDTA, $1 \mathrm{ml} \mathrm{l}^{-1} \mathrm{HCl} 36 \%$ and $0.5 \mathrm{~g} \mathrm{l}^{-1}$ resazurin in demineralized water. Macronutrient solution was composed of $170 \mathrm{~g} \mathrm{l}^{-1} \mathrm{NH}_{4} \mathrm{Cl}, 8 \mathrm{~g} \mathrm{l}^{-1} \mathrm{CaCl}_{2} \cdot 2 \mathrm{H}_{2} \mathrm{O}$ and $9 \mathrm{~g} \mathrm{l}^{-1}$ $\mathrm{MgSO}_{4} \cdot 7 \mathrm{H}_{2} \mathrm{O}$ in demineralised water.

\section{Biodegradability experiments}

The biodegradability experiments were conducted to investigate the following aspects: the percentage biodegradable matter, the biodegradation rate constant $k$, and the factors affecting the biodegradation process. A total of 54 fresh composite samples were used to perform 98 tests i.e. 54 aerobic and 44 anaerobic tests (Table 1). The investigated variables were inoculum addition, incubation time, temperature and the COD fractions of the grey water. The biodegradability was identified by measuring BOD, $\mathrm{CH}_{4}-\mathrm{COD}$, or COD mineralized fraction. The biodegradation rate constant $(k)$ was calculated.

\section{Tests setups}

Biodegradability tests were performed in $510 \mathrm{ml}$ bottles, filled with test medium $250 \mathrm{ml}$ for aerobic and $300 \mathrm{ml}$ for anaerobic conditions. The liquid volume of the aerobic test was chosen for sufficient headspace for oxygen availability according to APHA (1995).

The tested samples were $100 \%$ grey water, $66 \%$ and $50 \%$ grey water diluted with distilled water, $2.5 \mu \mathrm{m}$ paper filtered grey water, membrane filtered grey water, and glucose solution as a reference. Tests without inoculum were fed with $248 \mathrm{ml}$ grey water sample for the aerobic tests and $288 \mathrm{ml}$ for the anaerobic tests. Tests with inoculum were fed with $228 \mathrm{ml}$ sample and $20 \mathrm{ml}$ inoculum for the aerobic tests and $268 \mathrm{ml}$ sample and $20 \mathrm{ml}$ inoculum for the anaerobic tests. Micronutrients and macronutrient, each $1 \mathrm{ml}$, were added to all bottles in each test, and for the anaerobic tests $10 \mathrm{ml}$ of $10 \mathrm{mM}$ phosphate buffer was added. The tests were conducted in duplicate according to the setup in Table 1. Additionally for each test a blank was included where distilled water replaced the grey water sample.

The gas phase of the anaerobic bottles was flushed for $5 \mathrm{~min}$ with nitrogen gas to create anaerobic 
Table 1 Aerobic and anaerobic biodegradability test setups: tested grey water fractions and the variables

\begin{tabular}{|c|c|c|c|c|c|}
\hline \multirow[t]{2}{*}{ Test } & \multirow[t]{2}{*}{ Grey water fraction } & \multicolumn{4}{|l|}{ Variables } \\
\hline & & Inoculum $(-$ or +$)$ & Temperature $\left({ }^{\circ} \mathrm{C}\right)$ & Incubation time (days) & Dilution $(-$ or +$)$ \\
\hline \multirow[t]{11}{*}{ Aerobic } & \multirow[t]{6}{*}{ Total (38) } & \multirow[t]{2}{*}{$-(30)$} & \multirow[t]{2}{*}{$20(30)$} & $28(30)$ & $-(30)$ \\
\hline & & & & $60(6)$ & $-(6)$ \\
\hline & & \multirow[t]{4}{*}{$+(8)$} & $20(2)$ & $28(2)$ & $-(2)$ \\
\hline & & & $25(4)$ & $28(2)$ & $-(2)$ \\
\hline & & & & & $+(2)$ \\
\hline & & & $35(2)$ & $28(2)$ & $-(2)$ \\
\hline & \multirow[t]{2}{*}{ Paper-filtrate (8) } & $-(6)$ & $20(2)$ & $60(6)$ & $-(6)$ \\
\hline & & $+(2)$ & $35(2)$ & $28(2)$ & $-(2)$ \\
\hline & \multirow[t]{2}{*}{ Membrane-filtrate (8) } & $-(6)$ & $20(2)$ & $60(6)$ & $-(6)$ \\
\hline & & $+(2)$ & $35(2)$ & $28(2)$ & $-(2)$ \\
\hline & Glucose* & $+(1)$ & $25(1)$ & $6(1)$ & $-(1)$ \\
\hline \multirow[t]{11}{*}{ Anaerobic } & \multirow[t]{6}{*}{ Total (32) } & \multirow[t]{2}{*}{$-(24)$} & \multirow[t]{2}{*}{$35(24)$} & $90(24)$ & $-(24)$ \\
\hline & & & & $160(4)$ & $-(4)$ \\
\hline & & \multirow[t]{4}{*}{$+(8)$} & $20(2)$ & $30(2)$ & $-(2)$ \\
\hline & & & $30(4)$ & $30(2)$ & $-(2)$ \\
\hline & & & & & $+(2)$ \\
\hline & & & $35(2)$ & $30(2)$ & $+(2)$ \\
\hline & \multirow[t]{2}{*}{ Paper-filtrate (6) } & $-(4)$ & $35(2)$ & $160(4)$ & $-(4)$ \\
\hline & & $+(2)$ & $35(2)$ & $98(2)$ & $-(2)$ \\
\hline & \multirow[t]{2}{*}{ Membrane-filtrate (6) } & $-(4)$ & $35(2)$ & $160(4)$ & $-(4)$ \\
\hline & & $+(2)$ & $35(2)$ & $98(2)$ & $-(2)$ \\
\hline & Glucose* & $+(1)$ & $30(1)$ & $6(1)$ & $-(1)$ \\
\hline
\end{tabular}

() number of the batches

* glucose used as a reference for comparing with grey water biodegradability tests. Performed under the same conditions as the grey water biodegradability tests but with glucose instead of grey water sample

conditions. Soda lime pellets were added in the gas phase to aerobic and anaerobic bottles to adsorb $\mathrm{CO}_{2}$. Aerobic bottles were re-aerated for $5 \mathrm{~min}$ after 28 days and the soda lime was checked to be active by testing the change in its colour. If the test was continued, re-aeration was applied every 10 days until the test finished. The anaerobic bottles were checked for the consumption of soda lime pellets after 30 days and re-checked every 30 days until the test finished. During the test period the pressure was released when the maximum pressure capacity of the barometric heads (Oxitop ${ }^{\circledR}$, WTW GmbH, Weilheim, Germany) was reached. Both in the aerobic and anaerobic tests the soda lime pellets did not require replacement. The activity of anaerobic and aerobic inocula was tested with glucose as carbon source. The tests were performed in the same manner as the biodegradability tests with inoculum. Instead of grey water, $300 \mathrm{mg} \mathrm{COD}^{-1}$ glucose solution was used.

To control the effect of use soda pellets for $\mathrm{CO}_{2}$ removal, on the measured conversion rate, anaerobic batch experiments with and without pellets were conducted. For testing this, anaerobic granular sludge was used with sufficient methangenic activity and a substrate concentration of $300 \mathrm{mg}$ glucose COD $\mathrm{l}^{-1}$, no effect of soda pellets was observed on the conversion rate.

\section{Analysis}

The COD was measured of each sample fraction according to the standard methods (APHA 1995) at the beginning and also at the end of the experiments if inoculum was not added. Pressure monitoring was 
done versus time by barometric Oxitop ${ }^{\circledR}$ (WTW $\mathrm{GmbH}$, Weilheim, Germany) measuring devices. The $\mathrm{pH}$ was monitored at the beginning and end of each biodegradability test, with a $\mathrm{pH}$ meter $(\mathrm{HACH}-$ HQ40Dc).

\section{Calculations}

\section{Grey water characteristics}

Grey water constituents are categorized into COD fractions $\left(\mathrm{COD}_{\text {fraction }}\right)$ being total $\left(\mathrm{COD}_{\text {tot }}\right)$, suspended solids $\left(\mathrm{COD}_{\mathrm{ss}}\right)$, colloidal $\left(\mathrm{COD}_{\mathrm{col}}\right)$ and dissolved $\left(\mathrm{COD}_{\mathrm{dis}}\right)$. The $\mathrm{COD}_{\mathrm{ss}}$ is the difference between the COD of the total and of $2.5 \mu \mathrm{m}$ paper filtered (No. 42 Whatman filter paper) grey water; the difference between the COD of the $2.5 \mu \mathrm{m}$ paper filtered and membrane filtered $(0.45 \mu \mathrm{m}$ membrane filter paper) grey water is $\mathrm{COD}_{\mathrm{col}}$. The COD of the filtrate of the membrane filtration is $\mathrm{COD}_{\text {dis }}$. The same principle is applied for characterizing the grey water in terms of BOD.

\section{Biodegradability characteristics}

The biodegradability is expressed in terms of the mineralized fraction (COD), biochemical oxygen demand (BOD) and biological methane potential (BMP). The biodegradation rate is expressed as oxygen consumption (BOD) rate and methane production rate.

Mineralized fraction Equations 1-4 in Table 2 were used to calculate the mineralized-COD fraction of the total, suspended, colloidal and dissolved components.
The particle size is expected to decrease during degradation. However, an increase in particle size may occur, owing to flocculation, cell yield and coagulation. In order to calculate the mineralization over time of a particle size fraction that was present at the start of the experiment, the calculated value needs to be corrected for the amount of produced particles over that time period. For instance, at time $=0$ the amount of $\mathrm{COD}_{\mathrm{ss}}$ is given by $\mathrm{A}_{1}-\mathrm{A}_{2}$ in Eq. 2, Table 2, whereas at time $=t$ the remaining amount of COD originating from $\operatorname{COD}_{\mathrm{ss}}(t=0)$ is given by $\mathrm{B}_{1}-\mathrm{C}_{1}$ in Eq. 2, Table 2. The result of Eqs. 1-4 will thus be the percentage of COD mineralization only.

$B O D$ and BMP calculations The pressure decrease $\Delta P$ was used to calculate the moles per litre of sample of $\mathrm{O}_{2}$ consumption (BOD) and the pressure increase $\Delta P$ to calculate the $\mathrm{CH}_{4}$ production (BMP) in moles per litre of sample using the ideal gas law given in Eq. 5.

$\mathrm{BOD}$ or BMP $\left(\mathrm{mol} \mathrm{l}^{-1}\right)=\frac{\Delta P V}{R T} \frac{1}{v}$

where $\Delta P$ the measured pressure change $(\mathrm{kPa}), V$ the bottle head-space volume (l), $R$ the gas constant (8.314 $\mathrm{J} \mathrm{K}^{-1} \mathrm{~mol}^{-1}$ ), $T$ the temperature $(\mathrm{K})$ and $v$ is the sample volume (1). The calculated moles per litre of sample were then converted into $\mathrm{mg} \mathrm{O}_{2}$ per litre of sample.

Biodegradation rate constants Aerobic and anaerobic first order biodegradation rate constants $(k)$ of the grey water fractions are calculated using Eq. 6 (Metcalf and Eddy 2003) and 7, respectively.

Table 2 Formulas to calculate mineralized \% COD per particle size fraction

\begin{tabular}{|c|c|c|c|c|c|c|c|c|c|}
\hline \multirow[b]{3}{*}{ COD fractions } & \multicolumn{9}{|c|}{ Bottles filled with } \\
\hline & \multicolumn{3}{|c|}{ Total (tot) sample* } & \multicolumn{3}{|c|}{ Paper filtrate (pf) sample } & \multicolumn{3}{|c|}{ Membrane filtrate (mf) sample } \\
\hline & tot & pf & $\mathrm{mf}$ & tot & $\mathrm{Pf}$ & $\mathrm{mf}$ & tot & $\mathrm{pf}$ & Mf \\
\hline At time $=0.0$ & $\mathrm{~A}_{1}$ & $\mathrm{~A}_{2}$ & $\mathrm{~A}_{3}$ & & $\mathrm{~A}_{2}$ & $\mathrm{~A}_{3}$ & & & $\mathrm{~A}_{3}$ \\
\hline \multirow{2}{*}{ At time $=t$} & $\mathrm{~B}_{1}$ & $\mathrm{~B}_{2}$ & $\mathrm{~B}_{3}$ & $\mathrm{C}_{1}$ & $\mathrm{C}_{2}$ & $\mathrm{C}_{3}$ & $\mathrm{D}_{1}$ & $\mathrm{D}_{2}$ & $\mathrm{D}_{3}$ \\
\hline & \multicolumn{9}{|c|}{ Mineralized COD fractions } \\
\hline COD & \multicolumn{2}{|c|}{$\mathrm{COD}_{\text {tot }}$} & \multicolumn{3}{|c|}{$\mathrm{COD}_{\mathrm{ss}}$} & \multicolumn{2}{|c|}{$\mathrm{COD}_{\mathrm{col}}$} & \multicolumn{2}{|c|}{$\mathrm{COD}_{\mathrm{dis}}$} \\
\hline Mineralized- fraction $(\%)=$ & \multicolumn{2}{|c|}{$\frac{A_{1}-B_{1}}{A_{1}} 100$} & \multicolumn{3}{|c|}{$\frac{\left(\mathrm{A}_{1}-\mathrm{A}_{2}\right)-\left(\mathrm{B}_{1}-\mathrm{C}_{1}\right)}{\mathrm{A}_{1}-\mathrm{A}_{2}} 100$} & \multicolumn{2}{|c|}{$\frac{\left(\mathrm{A}_{2}-\mathrm{A}_{3}\right)-\left(\mathrm{C}_{1}-\mathrm{D}_{1}\right)}{\mathrm{A}_{2}-\mathrm{A}_{3}} 100$} & \multicolumn{2}{|c|}{$\frac{A_{3}-D_{1}}{A_{3}} 100$} \\
\hline
\end{tabular}

The COD is derived from measurements of the COD of the liquid phase and the tests are conducted without inoculum and soda lime pellets

* total is the non-filtrated sample 
$\mathrm{BOD}_{\text {fra }-t}=\mathrm{BOD}_{\mathrm{U}-\mathrm{fra}}\left[1-\operatorname{Exp}\left(-k_{\mathrm{fra}} t\right)\right]$

where $\mathrm{BOD}_{\text {fra- } t}$ is $\mathrm{BOD}_{\text {tot }-t}, \mathrm{BOD}_{\mathrm{ss}-t}, \mathrm{BOD}_{\text {col- } t}$ or $\mathrm{BOD}_{\text {dis- } t}$ at time $=t$. $\mathrm{BOD}_{\mathrm{U}-\text { fra }}$ is the ultimate $\mathrm{BOD}_{\text {fra }}$ $\left(\mathrm{mg} \mathrm{l}^{-1}\right)$ and $k\left(\mathrm{day}^{-1}\right)$ the kinetic rate constant. Both $\mathrm{BOD}_{\mathrm{U}-\text { fra }}$ and $k$ are derived from the curve calculated with the Microsoft Excel solver function.

$\mathrm{CH}_{4}-\mathrm{COD}_{\text {fra }-t}=\mathrm{BMP}_{\text {fra }}\left[1-\operatorname{Exp}\left(-k_{\mathrm{fra}} t\right)\right]$

Where $\mathrm{CH}_{4}-\mathrm{COD}$ refers to methane production; $\mathrm{CH}_{4}-\mathrm{COD}_{\text {fra- } t}$ is $\mathrm{CH}_{4}-\mathrm{COD}_{\text {tot- } t}, \mathrm{CH}_{4}-\mathrm{COD}_{\text {ss- } t}, \mathrm{CH}_{4}-$ $\mathrm{COD}_{\text {col- } t}$ or $\mathrm{CH}_{4}-\mathrm{COD}_{\text {dis- } t}$, at time $=t . \quad \mathrm{BMP}_{\text {fra }}$ biological methane potential refers to the maximum $\mathrm{CH}_{4}-\mathrm{COD}_{\text {fra }}\left(\mathrm{mg} \mathrm{l}^{-1}\right)$ and $k$ the kinetic rate constant $\left(\right.$ day $\left.^{-1}\right)$. Both $\mathrm{BMP}_{\text {fra }}$ and $k$ are derived from the curve calculated with the Microsoft Excel solver function.

Temperature impact on rate constant $(k)$ measured by $(\theta)$ Equation 8 is derived from the Van't HoffArrhenius relationship (Metcalf and Eddy 2003), and $\theta$ is the exponential of the slope $\ln (\theta)$.

$\ln \left(\frac{k_{T_{1}}}{k_{T_{2}}}\right)=\left(T_{1}-T_{2}\right) \ln \left(\theta_{20-35}\right)$

Where $k_{T_{1}}$ and $k_{T_{2}}$ are the kinetic rate constants (day $^{-1}$ ) at $T_{1}$ and $T_{2}$ respectively, $T$ the temperature, in the range $20-35^{\circ} \mathrm{C}$, and $\theta$ the temperature coefficient. Values of $k$ are calculated from Eqs. 6 and 7.

Reactor design To study the implication of biodegradability experiments results on the reactor design Eq. 9 is derived, based on mass balance; assuming CSTR, steady state conditions and first order kinetics, is applied to calculate the digestion time (SRT) required in a CSTR, assuming steady state, to digest grey water total pollutants for aerobic and suspended for anaerobic treatment.

$\mathrm{SRT}=\frac{C_{0}-C_{t}}{k C_{t}}$

Where SRT is the sludge retention time (days), $k$ the kinetic rate constant $\left(\right.$ day $\left.^{-1}\right)$ of the total or suspended samples $\left(k_{\mathrm{tot}}\right), C_{0}$ the initial and $C_{t}$ the concentration of digestible substrate at SRT $=t\left(\mathrm{mg} \mathrm{COD}_{\mathrm{tot}} \mathrm{l}^{-1}\right)$.

\section{Results and discussion}

The characteristics of grey water from the dormitory at Jordan university campus are summarized in Tables $(3,4,5)$ and Fig. 1 . The concentration of the different fractions is presented in Table 3. The effect of applying different conditions in the biodegradation test is shown in Fig. 1. The maximum biodegradability is reported in Table 4, and the bioconversion rate constant and the temperature impact on the rate in Table 5.

Grey water characteristics

The investigated grey water consisted of combined wastewater from laundry, shower and hand washbasins. The pollutants of these wastewaters include detergents and components washed from humans and/or textile. The results showed that the COD of the paper filtrates $8 \mu \mathrm{m}$ and $2.5 \mu \mathrm{m}$ are similar. Table 3, therefore, gives the COD of the total grey water and the suspended solids, colloidal and soluble percentage of the grey water.

The COD of Jordanian dormitory grey water, as measured in this study, is less than half of the concentrations reported for grey water measured by
Table 3 Grey water COD fractions found in this study and in the literature
(), standard deviation

[], number of samples

\begin{tabular}{|c|c|c|c|c|}
\hline \multirow[t]{2}{*}{ COD } & \multirow[t]{2}{*}{ Units } & \multicolumn{3}{|l|}{ Grey water sources } \\
\hline & & $\begin{array}{l}\text { Dormitory at Jordan } \\
\text { University Campus }\end{array}$ & $\begin{array}{l}\text { Sneek in Groningen, } \\
\text { The Netherlands }\end{array}$ & $\begin{array}{l}\text { Flintenbreite' } \\
\text { settlement } \\
\text { Luebeck-Germany }\end{array}$ \\
\hline Total & $\operatorname{mg~} 1^{-1}$ & $362(100)[54]$ & 827 (204) & 649 (124) \\
\hline Suspended & $\%$ & 28 (9) [54] & 49 & 50 \\
\hline Colloidal & $\%$ & $32(8)[54]$ & 24 & 30 \\
\hline Dissolved & $\%$ & 40 (7) [54] & 27 & 20 \\
\hline References & & This study & Hernandez et al. (2008) & $\begin{array}{l}\text { Elmitwalli and } \\
\text { Otterpohl (2007) }\end{array}$ \\
\hline
\end{tabular}


Table 4 Mineralized COD fraction, $\mathrm{BOD}_{\mathrm{U}}$ and $\mathrm{BMP}$ as a percentage of the influent COD for total grey water and the various fractions

\begin{tabular}{|c|c|c|c|c|c|c|}
\hline \multirow[t]{2}{*}{ Tests } & \multirow[t]{2}{*}{ Parameters } & \multicolumn{4}{|c|}{ Mineralized COD fractions } & \multirow[b]{2}{*}{ Sludge } \\
\hline & & Total (tot) $\%$ & $\begin{array}{l}\text { Suspended } \\
\text { (ss) } \%\end{array}$ & $\begin{array}{l}\text { Colloidal } \\
\text { (col) } \%\end{array}$ & $\begin{array}{l}\text { Dissolved } \\
\text { (dis) } \%\end{array}$ & \\
\hline \multirow[t]{3}{*}{ Aerobic biodegradation } & $* \mathrm{COD}_{28 \mathrm{~d}-20^{\circ} \mathrm{C}}$ & $62(6)[30]$ & & & & No \\
\hline & $* \mathrm{COD}{ }_{60 \mathrm{~d}-20^{\circ} \mathrm{C}}$ & 86 (4) [6] & 78 (1) [6] & $90(3)[6]$ & 87 (2) [6] & No \\
\hline & $* * \mathrm{BOD}_{\mathrm{U}-28 \mathrm{~d}-20^{\circ} \mathrm{C}} / \mathrm{COD}$ & 82 (4) [2] & $76(5)[2]$ & $85(6)[2]$ & $86(4)[2]$ & Yes \\
\hline \multirow[t]{3}{*}{ Anaerobic biodegradation } & $* \mathrm{COD}_{90 \mathrm{~d}-35^{\circ} \mathrm{C}}$ & 44 (13) [24] & & & & No \\
\hline & $* \mathrm{COD}_{160 \mathrm{~d}-35^{\circ} \mathrm{C}}$ & $70(6)[4]$ & $60(6)[4]$ & 77 (6) [4] & $71(1)[4]$ & No \\
\hline & $* * \mathrm{BMP}_{98 \mathrm{~d}-35^{\circ} \mathrm{C}} / \mathrm{COD}$ & $57(5)[2]$ & $51(3)[2]$ & $67(7)[2]$ & $56(3)[2]$ & Yes \\
\hline \multicolumn{7}{|l|}{ (), standard deviations } \\
\hline \multicolumn{7}{|l|}{ [], number of the batches } \\
\hline * only based on determine & DD removal & & & & & \\
\hline
\end{tabular}

Table 5 The effect of temperature on anaerobic and aerobic degradation rate constants of grey water

\begin{tabular}{|c|c|c|c|c|c|c|c|}
\hline \multirow[t]{2}{*}{ Tests } & \multirow[t]{2}{*}{ Parameters } & \multirow[t]{2}{*}{ Units } & \multicolumn{4}{|l|}{ COD-Fractions (fra) } & \multirow[t]{2}{*}{ Sludge } \\
\hline & & & Total & Suspended & Colloidal & Dissolved & \\
\hline \multirow{3}{*}{$\begin{array}{l}\text { Aerobic } \\
\text { biodegradation }\end{array}$} & $k_{20^{\circ} \mathrm{C}}$ & day $^{-1}$ & $0.119(0.005)[2]$ & & & & \multirow[t]{3}{*}{ Yes } \\
\hline & $k_{25^{\circ} \mathrm{C}}$ & day $^{-1}$ & $0.174(0.006)[2]$ & & & & \\
\hline & $k_{35^{\circ} \mathrm{C}}$ & day $^{-1}$ & $0.318(0.004)[2]$ & $0.334(0.004)[2]$ & $0.343(0.005)[2]$ & $0.264(0.004)[2]$ & \\
\hline \multirow{3}{*}{$\begin{array}{l}\text { Anaerobic } \\
\text { biodegradation }\end{array}$} & $k_{20^{\circ} \mathrm{C}}$ & day $^{-1}$ & $0.005(0.0008)[2]$ & & & & \multirow[t]{3}{*}{ Yes } \\
\hline & $k_{30^{\circ} \mathrm{C}}$ & day $^{-1}$ & $0.011(0.001)[2]$ & & & & \\
\hline & $k_{35^{\circ} \mathrm{C}}$ & $\mathrm{day}^{-1}$ & $0.023(0.001)[2]$ & $0.069(0.002)[2]$ & $0.036(0.001)[2]$ & $0.011(0.001)[2]$ & \\
\hline
\end{tabular}

(), standard deviations

[], number of the batches

Elmitwalli and Otterpohl (2007) and Hernandez et al. (2008) (Table 3). The likely reason for this is that the dormitory grey water used in this study is a combination of shower, laundry and washbasin streams, whereas the wastewater sources of the other two studies include the kitchen stream. The kitchen wastewater is the most concentrated stream in terms of COD and has the highest content of suspended solids (Abu Ghunmi et al. 2008).

\section{Biodegradability characteristics}

\section{Influencing factors}

The biodegradability of grey water is affected by the inoculum addition, applied incubation time and temperature (Fig. 1). The addition of inoculum has, at a degradation time of 28 days, a positive effect on

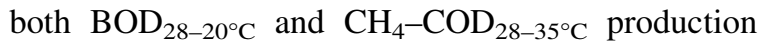
(Fig. 1a). This is attributed to the lack of initial natural microbial activity in the grey water, which is insufficient in a period of 28 days compared to tests where inoculum has been added. However, when the incubation time of the mineralization tests without inoculum is extended, the amount of mineralized COD increases (Fig. 1b). Theoretically, not adding inoculum has no influence at infinite time scales because ultimately the few microorganisms present in the grey water will multiply and have ample time to degrade all substrate. In practice, however, shorter time scales are relevant and adding adapted inoculum will accelerate the degradation process. The effect of increasing temperature on the biodegradation is, like adding inoculum, an increase in $\mathrm{BOD}_{5}$ and $\mathrm{CH}_{4}-\mathrm{COD}_{28}$ 

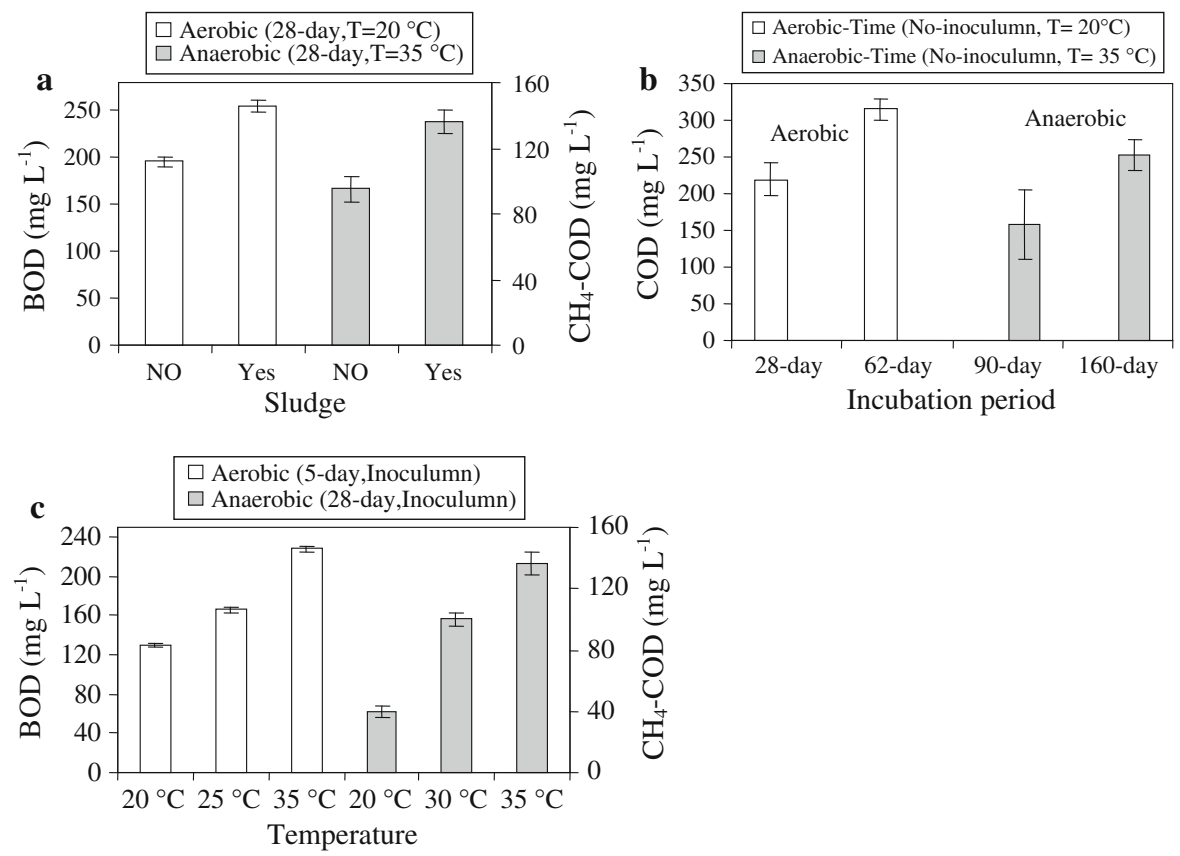

Fig. 1 a Effect of adding inoculum on $\mathrm{BOD}_{28-20^{\circ} \mathrm{C}}\left(\mathrm{mg} \mathrm{l}^{-1}\right)$

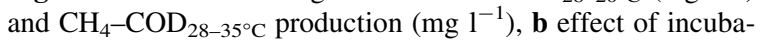
tion time on the aerobic and anaerobic COD mineralized fraction $\left(\mathrm{mg} \mathrm{l}^{-1}\right)$ and $\mathbf{c}$ effect of temperature on the $\mathrm{BOD}_{5}$

production caused by microbial activity that accelerates with rising temperature (Fig. 1c).

\section{Biodegradability}

The biodegradability measured as COD mineralized amount, BOD and/or $\mathrm{CH}_{4}-\mathrm{COD}$ varies largely with inoculation, temperature and degradation time as shown in Fig. 1. Finding the Ultimate BOD $\left(\mathrm{BOD}_{\mathrm{U}}\right)$ and maximum $\mathrm{CH}_{4}-\mathrm{COD}$ i.e. Biological methane potential (BMP) minimizes these variations to a single value. Figure $2 \mathrm{a}$ and $\mathrm{b}$ show the cumulative $\left(\mathrm{mg} \mathrm{l}^{-1}\right)$ and $\mathrm{CH}_{4}-\mathrm{COD}_{28}\left(\mathrm{mg} \mathrm{l}^{-1}\right)$ production. Experiment variables and between brackets the experiment fixed conditions. All samples are total grey water

oxygen consumption (BOD) and methane production $\left(\mathrm{CH}_{4}-\mathrm{COD}\right)$ versus time of the grey water. The maximum biodegradation is reached where the lines level horizontally. In Table 4 the $\mathrm{BOD}_{\mathrm{U}}$ and $\mathrm{BMP}$ are given as percentage of the influent COD.

For aerobic biodegradability: The $\mathrm{BOD}_{\mathrm{U}} / \mathrm{COD}_{\text {tot }}$ represents the maximum biodegradable percentage, $82 \%$, of dormitory grey water pollutants. Comparing $\mathrm{BOD}_{\mathrm{U}} / \mathrm{COD}_{\text {tot }}$ with mineralized-COD after 28 days and after 60 days, in Table 4, approves for measuring and getting single value for grey water biodegradability, within a reasonable period of time adding seed is a
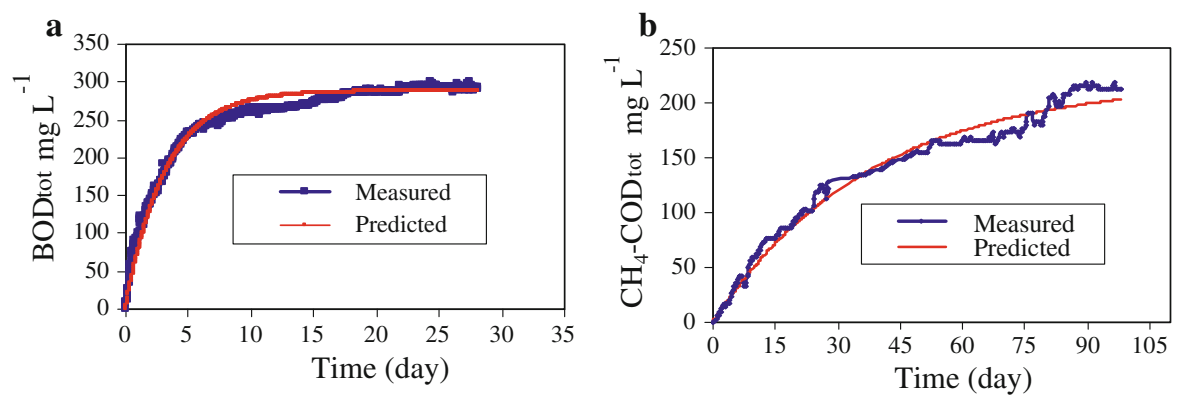

Fig. 2 a BOD and b $\mathrm{CH}_{4}-\mathrm{COD}$ production versus time of total grey water. Test was performed with inoculums at $35^{\circ} \mathrm{C}$. The predicted values were calculated for the aerobic tests using equation 4.6 and for anaerobic tests equation 4.7 
must. For anaerobic biodegradability: the BMP/ $\mathrm{COD}_{\text {tot }}$ represents the maximum biodegradable percentage, $57 \%$, of dormitory grey water pollutants. $\mathrm{BMP} / \mathrm{COD}_{\text {tot }}$ is slightly lower than the mineralizedCOD fraction after 160 days anaerobic incubation. The reasons could be that the mineralization on the basis of COD can be overestimated when substrate adsorbs over time to the bottle walls, such as lipids (Sanders 2001), and is not sampled for the determination of the end COD. Furthermore, measuring anaerobic biodegradation by means of pressure monitoring in the presence of soda lime pellets to exclude $\mathrm{CO}_{2}$ might affect "reduce" the biodegradable fraction, this negative effect might be due to an increase of the $\mathrm{pH}$ (Pabon et al. in prep). However, the $\mathrm{pH}$, in this study, did not change between the starting, $7.5 \pm 0.5$, and the end, $7.2 \pm 0.5$, of the experiments viz. 98 days. Moreover, when testing the pressure development on glucose (this study, results not presented), for 3 days, at 300 and 1,200 $\mathrm{mg} \mathrm{COD}^{-1}$ with and without soda lime pellets the $\mathrm{pH}$ remained within (6.5-7.5) favourable operation limits or did not change at all.

In Table 4 mineralization of total grey water and the fractions is shown. Under aerobic and anaerobic conditions the conversion percentages of the colloidal (col) and dissolved (dis) fractions are significantly higher $(t$ values $>2$ ) than the conversion percentage of the suspended (ss) fraction.

The $\mathrm{BOD}_{5} / \mathrm{COD}$ ratios of $43 \pm 4$, found in this study for a temperature of $20^{\circ} \mathrm{C}$ are within the range found in literature of 25-64\% (Jefferson et al. 1999; Friedler et al. 2005, 2006; Winward et al. 2008). The anaerobic biodegradability values found in this study, where kitchen wastewater is excluded, for the

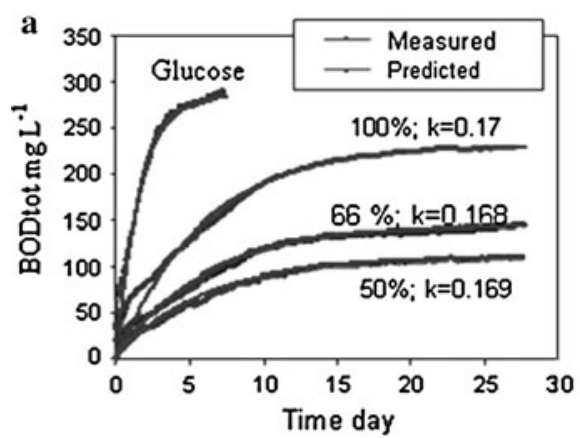

Fig. 3 a BOD for 100, 66 and $50 \%$ and b $\mathrm{CH}_{4}-\mathrm{COD}$ production for 100 , and $50 \%$ grey water sample in water versus time, with glucose as a reference. The degradation tests were performed with inoculums and soda lime pellets at $25^{\circ} \mathrm{C}$ different $\mathrm{COD}_{160 \text {-days }}$ fractions (Table 4) are lower than the values reported by Elmitwalli and Otterpohl (2007); where kitchen wastewater is included. The anaerobic biodegradability values are $74 \%$ for total grey water, $70 \%$ for suspended solids, $84 \%$ for colloidal matter and $70 \%$ for the dissolved fraction.

\section{Biodegradation rate}

The amount of biodegradable matter digested in a certain period of time, which is linked to the kinetic rate constants $(k)$, varies with the inoculum addition and temperature (Fig. 1a and c). To minimize the variation in the measured values of $k$, the mineralization process should not be limited by inoculum availability, but only by the nature of the organic matter. Figure $3 a$ and $b$ show that the oxygen consumed (BOD) or methane produced (BMPCOD) versus time is apparently not limited by the biomass availability. As at different dilutions of grey water the amount of oxygen consumed or methane produced $(\mathrm{mg})$ versus time was inversely proportional to the dilution. Furthermore, the degradation rate of grey water was compared to a reference sample containing glucose, easy biodegradable compound, as carbon source under the same conditions. The results show grey water biodegradation rate (Table 5) was $4 \times$ slower aerobically $\left(k_{\text {tot-25 }}\right)$ and $12 \times$ slower anaerobically $\left(k_{\text {tot-30 }}\right)$ than with the glucose. Thus the grey water biodegradation rate is apparently limited by the chemical nature of its constituents.

The overall aerobic grey water biodegradation rate $\left(k_{\mathrm{tot}}\right)$ is higher than the anaerobic rate, for instance, at $20^{\circ} \mathrm{C}$ the aerobic rate is 24 times higher than the

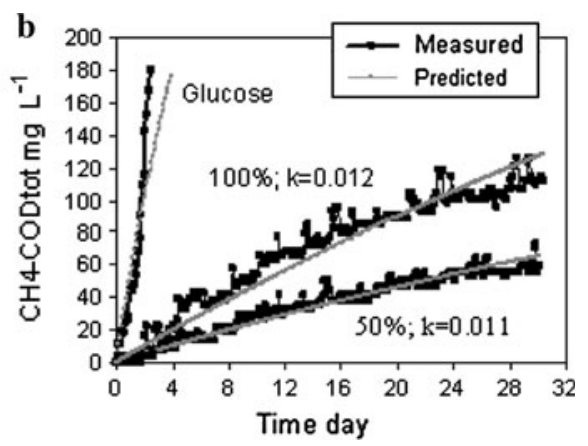

for aerobic and $30^{\circ} \mathrm{C}$ for anaerobic conditions. The predicted values were calculated for the aerobic tests using equation 4.6 and for anaerobic tests equation 4.7 
anaerobic rate (Table 4). Meanwhile both the aerobic and anaerobic rates are lower than the aerobic biodegradation rate of domestic wastewater $\left(k_{20}{ }^{\circ} \mathrm{C}\right.$ 0.23 day $^{-1}$ ) (Metcalf and Eddy 2003). Grey water aerobic and anaerobic biodegradation rates can be described by first order kinetics (Figs. 2a and b; 3a and $b$ ). The different COD fractions in grey water are degraded at different rates (Fig. 2a and b; Table 5). The dissolved fraction is biodegraded at the lowest rate, both for aerobic and anaerobic conditions (Table 5). The increase in temperature from 20 to $35^{\circ} \mathrm{C}$ results in an exponential increase in the rate constants values $(k)$ (Fig. 4a and b), which can be described via an Arrhenius relation, with an Arrhenius coefficient $\theta_{20-35}$ of 1.069 for aerobic and 1.099 for anaerobic conditions.

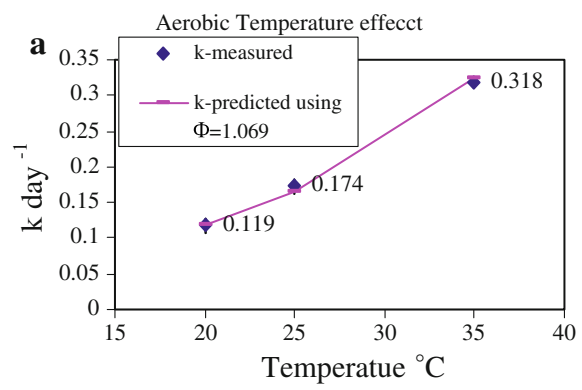

Fig. 4 a and b Aerobic and anaerobic first order biodegradation rate constants $(k)$ versus temperature. The tests were performed with added inoculums and soda lime pellets. The
Features of grey water biological processes

Designing biological processes for treatment of grey water, the parameters of concern are sludge retention time (SRT) and the temperature. In the winter time when the temperature in the reactor drops from 25 to $20^{\circ} \mathrm{C}$ the biodegradation rates show a $1.5 \times$ and $1.6 \times$ reduction for aerobic and anaerobic degradation, respectively (Table 5). The sludge retention should be sufficient to provide enough stabilisation time, and the reactor should be designed for $20^{\circ} \mathrm{C}$.

The anaerobic conversion of $\mathrm{COD}_{\mathrm{ss}}$ and aerobic conversion $\mathrm{COD}_{\text {tot }}$ as a function of time at $20^{\circ} \mathrm{C}$ were calculated, using Eq. 9, and depicted in Fig. 5. It shows that long an SRT is required to treat grey water, both anaerobically and aerobically. For example, for $60 \%$

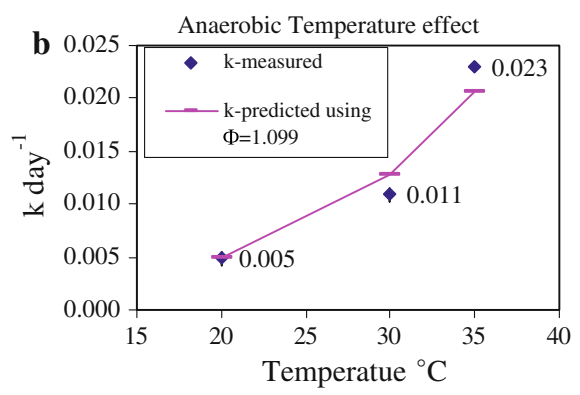

calculated $k$ is derived from equations 4.6 and 4.7 and the predicted $k$ is based on the calculated values of $\theta_{20-35}$, from equation 4.8
Fig. 5 Grey water aerobic and anaerobic treatment in a continuous stirred tank reactor (CSTR): SRT versus COD converted fraction at $20^{\circ} \mathrm{C}$. A refers to Aerobic and An refers to Anaerobic. The two small inset drawings zoom in the scale from 0.0 to 0.6 to depict the trends

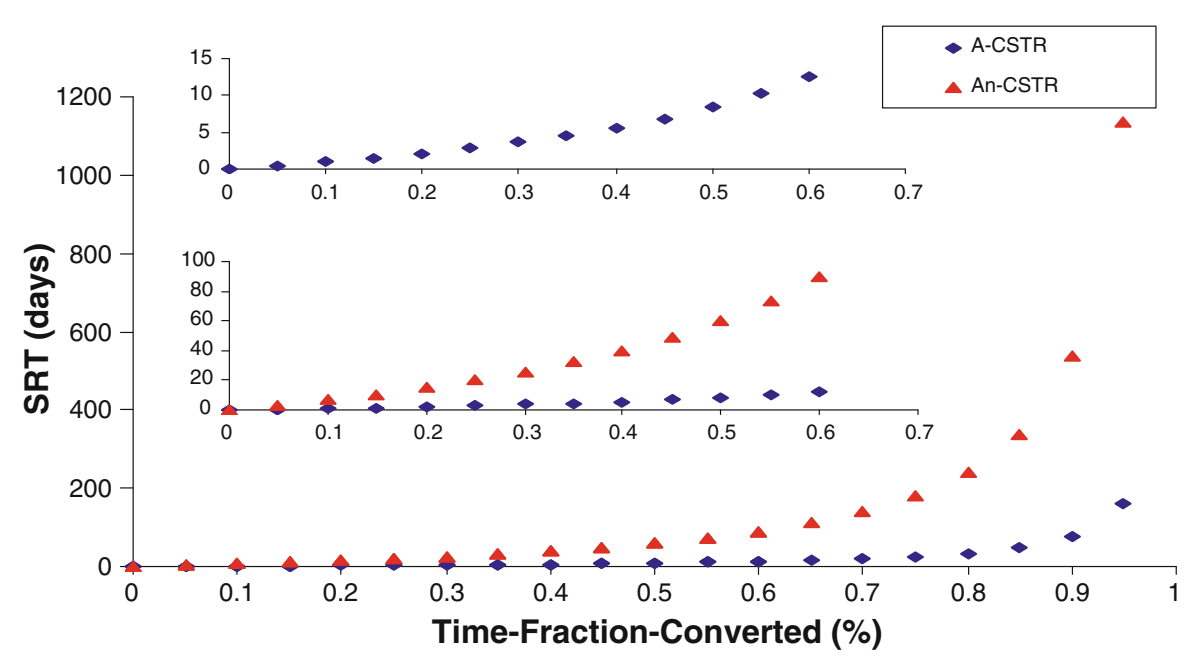


digestibility $\mathrm{COD}_{\mathrm{ss}}$ requires 90 days SRT anaerobically and $\mathrm{COD}_{\text {tot }}$ requires 12.6 days SRT aerobically. As a consequence, a reasonable treatment in terms of time and volume requires that the applied unit should have the capacity to trap pollutants in a short hydraulic retention time (HRT), while also maintaining a sufficient SRT for treatment. For example, Elmitwalli and Otterpohl (2007) treated grey water in an UASB at an HRT of 6, 10 and $16 \mathrm{~h}$, and at minimum SRT of 27, 64, and 93 days respectively, the $\mathrm{COD}_{\mathrm{ss}}$ removal efficiencies were $68 \pm 17,79 \pm 8$ and $83 \pm 5 \%$ respectively.

\section{Conclusions}

Grey water, including laundry, hand washbasin and shower wastewater, is characterised by a suspended, colloidal and dissolved COD fraction of respectively 28, 32 and $40 \%$.

Incubation time, inoculum addition, and temperature affect the aerobic and anaerobic biodegradability results.

The maximum biodegradability of the suspended COD fraction in grey water is lowest in comparison with the colloidal and dissolved fraction.

The biodegradation of grey water and the 3 distinguished COD fractions can be described with first order kinetics.

The dissolved COD fraction of domestic wastewater is degraded at the lowest rate.

Grey water aerobic and anaerobic treatment, at $20^{\circ} \mathrm{C}$, needs long SRT; for instance 12.6 days to remove $60 \%$ of $\mathrm{COD}_{\mathrm{ss}}$ aerobically, and 90 days to remove $60 \% \mathrm{COD}_{\text {tot }}$ anaerobically.

Acknowledgment The research, upon which this paper has been based, is funded by the Dutch Ministry of Foreign Affairs (Nuffic).

\section{References}

Abu Ghunmi L, Zeeman G, van Lier J, Fayyad M (2008) Quantitative and qualitative characteristics of grey water for reuse requirements and treatment alternatives: the case of Jordan. Water Sci Technol 58(7):1385-1396

Abu Ghunmi L, Zeeman G, Fayyad M, van Lier JB (2010) Grey water treatment in a series anaerobic-aerobic system for irrigation. Bioresour Technol 101(9):41-50

Alphenaar A (1994) Anaerobic granular sludge: characterization and factors affecting its functioning. Ph.D. Thesis, Wageningen University, The Netherlands
Angelidaki I, Sanders W (2004) Assessment of the anaerobic biodegradability of macropollutants. Rev Environ Sci Biotechnol 3:117-129

APHA (1995) Standard methods for the examination of water and wastewater, 19th edn. American Public Health Association, Washington, DC

Berna J, Battersby N, Cavalli L, Fletcher R, Guldner A, Schowanek D, Steber J (1999) Anaerobic biodegradation of surfactants: scientific review. Foreword and position paper (ERASM: Environmental Risk Assessment Steering Committee-a detergent industry group). Available at www.lasinfo.org/pos_papers/pos_paper_bioanaerobia.pdf. Accessed 20 Oct 2008

Christova-Boal D, Eden R, McFarlane S (1995) An investigation into grey water reuse for urban residential properties. Desalination 106(1-3):391-397

Dixon A, Butler D, Fewkes A, Robinson M (1999) Measurement and modelling of quality changes in stored untreated grey water. Urban Water 1(4):293-306

Elmitwalli T, Otterpohl R (2007) Anaerobic biodegradability and treatment of grey water in upflow anaerobic sludge blanket (UASB) reactor. Water Res 41(6):1379-1387

Eriksson E, Auffarth K, Henze M, Ledin A (2002) Characteristics of grey water. Urban water 4(1):85-104

Friedler E, Kovalio R, Galil N (2005) On-site grey water treatment and reuse in multi-story buildings. Water Sci Technol 51(10):187-194

Friedler E, Kovalio R, Ben-zvi A (2006) Comparative study of the microbial quality of grey water treated by three on-site treatment systems. Environ Technol 27(6):653-663

Hernandez L, Zeeman G, Temmink H, Buisman C (2007) Characterization and biological treatment of grey water. Water Sci Technol 56(5):193-200

Hernandez L, Zeeman G, Temmink H, Marques A, Buisman C (2008) Comparison of three systems for biological grey water treatment. In: Proc. IWA conference on Sanitation challenges, Wageningen, Netherlands, May 19-22

Jefferson B, Laine A, Parsons S, Stephenson T, Judd S (1999) Technologies for domestic wastewater recycling. Urban Water 1(4):285-292

Jefferson B, Laine A, Parsons S, Stephenson T, Judd S (2000) Membrane bioreactors and their role in wastewater reuse. Water Sci Technol 41(1):197-204

Jefferson B, Laine A, Parsons S, Stephenson T, Judd S (2001) Advanced biological unit processes for domestic water recycling. Water Sci Technol 43(10):211-218

Jefferson B, Palmer A, Jeffrey P, Stuetz R, Judd S (2004) Grey water characterization and its impact on the selection and operation of technologies for urban reuse. Water Sci Technol 50(2):157-164

Kujawa-Roeleveld K, Zeeman G (2006) Anaerobic treatment in decentralised and source-separation-based sanitation concepts. Rev Environ Sci Biotechnol 5(1):15-139

Li Z, Gulyas H, Jahn M, Gajurel D, Otterphohl R (2003) Grey water treatment by constructed wetlands in combination with $\mathrm{TiO}_{2}$-based photocatalytic oxidation for suburban and rural areas without sewer system. Water Sci Technol 48(11-12):101-106

Metcalf Eddy (2003) Wastewater engineering treatment and reuse: treatment, disposal, reuse, 3rd edn. McGraw-Hill, New York 
Nolde E (1999) Greywater reuse systems for toilet flushing in multi-story buildings-over ten years experiences in Berlin. Urban Water 1(4):275-284

Ramon G, Green M, Semiat R, Dosortez C (2004) Low strength gray water characterization and treatment by direct membrane filtration. Desalination 170(3):241-250

Rivero M, Parsons S, Jeffrey P, Pidou M, Jefferson B (2006) Membrane chemical reactor (MCR) combining photocatalysis and microfiltration for grey water treatment. Water Sci Technol 53(3):173-180

Sanders W (2001) Anaerobic hydrolysis during digestion of complex substrate. $\mathrm{PhD}$, Thesis, Wageningen University, The Netherlands

Shin H, Lee S, Seo S, Kim G, Lim K, Song J (1998) Pilot-Scale SBR and MF operation for the removal of organic compounds form grey water. Water Sci Technol 38(6):79-88
Winward G, Avery L, Frazer-Williams R, Pidou M, Jeffrey P, Stephenson T, Jefferson B (2008) A study of the microbial quality of grey water and an evaluation of treatment technologies for reuse. Ecol Eng 32(2):187-197

Pabon C, Catanares G, van Lier J (in prep) Optimizing an Oxtiop protocol for BMP determination of plant material Zeeman G, Kujawa K, de Mes T, Hernandez L, de Graff M, Abu Ghunmi L, Mels A, Meulman B, Temmink H, Buisman C, van Lier J, Lettinga G (2008) Anaerobic treatment as a core technology for energy, nutrients and water recovery from source-separated domestic waste (water). Water Sci Technol 57(8):1207-1212 